\title{
POLICE, PROSECUTION, COURTS AND WARTIME DEMONSTRATIONS: \\ ADELA PANKHURST IN THE AUSTRALIAN HIGH COURT
}

\author{
Jocelynne A Scutt
}

\begin{abstract}
Rights of assembly and freedom of speech are a rich ground for decisionmaking by police, prosecutors and courts in determining a balance with obligations of authorities to keep the peace and prevail against disorderly conduct or riot. Recent claims of abuse of police powers through "kettling" have reached the European Court of Justice. These cases directly address the scope and exercise of police authority in maintaining order during demonstrations. Yet not only police powers are in issue at times of political disputation. Two cases heard early last century by the Australian High Court illustrate the way in which both the decision to prosecute and judicial decision-making may be influenced by socio-political considerations, particularly in time of war. Pankhurst $v$ Porter and Pankhurst $v$ Kiernan saw Adela Pankhurst, youngest daughter in the redoubtable Pankhurst family of Suffragette fame, testing the limits of the law during the struggles to ensure that sending wheat abroad to feed the troops would not justify pricing bread out of the reach of ordinary, working-class households. The success of the appeal in Pankhurst $v$ Porter exposed error in the prosecutorial process. The failure of the appeal in Pankhurst $v$ Kiernan exposed flawed reasoning in the majority opinion and the strength of the dissenting judgment in it's application of the law to the facts and the need to maintain objectivity or at least neutrality as to the particular appellant.
\end{abstract}

\section{INTRODUCTION}

Engagement in war almost inevitably triggers developments in the law relating to freedom of association and the right to demonstrate. Most recently in the United Kingdom this has centred on demonstrations against the war in

* The Hon Dr Jocelynne A Scutt, Barrister \& Human Rights Lawyer, Visiting Fellow, Lucy Cavendish College, University of Cambridge, Visiting Professor, University of Buckingham. 
Iraq and invasion of Afghanistan, particularly where "kettling" has been employed by police to "manage" crowds. The use of police cordons to contain large numbers of protestors, so as to prevent their leaving an area, sometimes for hours, has been asserted as false imprisonment and/or a breach of the European Convention on Human Rights (the Convention). The Convention asserts that there is an absolute right not to be deprived of liberty unless particular, well-defined situations or circumstances exist. The question therefore arises as to whether kettling constitutes unlawful conduct on the part of police.

In Austin $v$ Metropolitan Police Commissioner ${ }^{1}$ the issue arose in the context of anti-capitalist protests in London in 2001. As a precursor to cases involving kettling and anti-war protestors, the Austin case has gone through the United Kingdom courts to the European Court of Justice, the argument centring upon whether such containment can be justified where police believe all held inside the cordon are demonstrators poised to commit a breach of the peace. In 2007 the Court of Appeal upheld the first instance determination that the police action was justified through their perception of "imminent risk". Kettling constituted deprivation of liberty amounting to false imprisonment, said the Court, unless the threshold test of "immediate risk or imminence" was met. Once immediate risk or imminence was found, then, so long as the force was proportionate to prevent a breach of the peace, kettling was lawful.

In 2009 this approach was upheld by the House of Lords. ${ }^{2}$ However, the argument has not ended there. The issue is going on appeal to the European Court of Justice, a principal contention being that if used effectively, the Public Order Act 1986 eliminates the need for kettling so that the imprisonment of demonstrators inherent in this "management" method remains unlawful, except in exceptional circumstances. If, contrary to or at the same time as applying the Public Order Act, police planning includes an intention to contain demonstrators in cordons depriving them of the right to move, this will eliminate the contention of "imminence" and "risk".

It is not only in contemporary times, however, that the use and potential abuse of institutional power have arisen for legal consideration. Austin illustrates the need for courtroom surveillance of the action of policing authorities in handling of demonstrations. There, the focus was on action that may ignore or overlook existing rights of police control under the law, when

\footnotetext{
${ }^{1}$ [2009] AC 564, [2009] 3 All ER 455.

2 Austin v Metropolitan Police Commissioner [2009] UKHL 5. See also H Fenwick "Marginalising Human Rights: Breach of the Peace, 'Kettling', the Human Rights Act and Public Protest" [2009] PL 737; R Smith "Rights and Wrongs: Turning off the Kettle: The Police Practice of Kettling Protesters is Overdue for Review” (2011) LS Gaz 6.
} 
authorities seek to extend police power and lawful state action beyond that required for maintenance of peace and good order. Yet problems go beyond police power, as two cases, almost one hundred years ago, illustrate. Pankhurst $v$ Porter $^{3}$ and Pankhurst $v$ Kiernan $^{4}$ confirm that scrutiny must extend to both the determination to prosecute and judicial decision-making.

Both cases were heard by the Australian High Court in 1917. In Pankhurst $v$ Porter, ${ }^{5}$ the question focused upon whether prosecution under a provision of the federal defence laws was sound. Here, the role of the prosecutor was under review. In Pankhurst $v$ Kiernan, ${ }^{6}$ the challenged charge was again under federal defence law. However, here, the question was whether the court itself might, in its judgment, be swayed by socio-political circumstances to make what was, ultimately, an unsustainable decision. Analysis of the judgments of the majority and that of the lone dissenter indicates that just as police and prosecutors may be swayed by socio-political circumstances in times of upheaval and unrest, judges are not immune.

\section{PANKHURST V PORTER - THE DECISION TO PROSECUTE}

In England, Adela Pankhurst worked as a trainee teacher in an economically impoverished area before joining her mother Emmeline Pankhurst and sisters Christabel and Sylvia in the Suffragette cause. ${ }^{7}$ Her arrival in Australia did not dissuade her from agitation. Working-class poverty was at the nub of the demonstration bringing her before the Victorian Court of Petty Sessions in August 1917.

According to the police prosecutor, "between five and six thousand" attended the rally, a protest against the rising price of bread. Wheat was being sent to Europe to feed the allied troops, affecting domestic supply. The magistrate was told that "shortly after three o'clock" on the day in question, Adela Pankhurst, Alice Suter and Jennie Baines, together with "several other women" appeared in the Treasury Gardens. ${ }^{8}$ According to the police prosecutor, Adela:

\footnotetext{
3 [1917] HCA 52; (1917) 23 CLR 504 (2 October 1917).

4 [1917] HCA 63; (1917) 24 CLR 120 (29 November 1917).

5 [1917] HCA 52; (1917) 23 CLR 504 (2 October 1917). (Page citations are from the [1917] HCA 52 online report.)

6 [1917] HCA 63; (1917) 24 CLR 120 (29 November 1917). (Page citations are from the [1917] HCA 63 online report.)

7 See V Coleman Adela Pankhurst - The Wayward Suffragette (Melbourne: Melbourne University Press, 1996) p 28ff.

${ }^{8}$ On the disappearance of Alice Suter from the historical record - apart from her being immortalised in newspaper reports and the Commonwealth Law Reports account of the appeal, see J A Scutt “The Woman Who Wasn't There: Alice Suter,
} 
“... got up on a seat and addressed the people assembled, and told them all to follow her to Parliament House in defiance of the police and to break in if necessary, and see what Billy Hughes [the Prime Minister] was going to do to get cheaper food for the starving people."

\section{Thereupon:}

"The crowd surged round the seat and the said Adela Constantia Mary Pankhurst was pushed off it, and then Alice Suter got up on the seat and commenced to address the people assembled, and she in turn was pushed off the seat, and also Jennie Baines was pushed off the seat, and then Adela Constantia Mary Pankhurst and Alice Suter and Jennie Baines went towards the steps of Parliament House arm-in-arm, and followed by the crowd of people." 10

Police then arrested the trio, who were prosecuted under regulation 27 of the 1916 War Precautions (Supplementary) Regulations, made on 14 August 1917. Regulation 27 being used against protestors for the first time meant the High Court faced a test case. The regulation stated:

1) It shall not be lawful for any number of persons exceeding twenty to meet in the open air in any part of the proclaimed place for any unlawful purpose or for the purpose or on the pretext of making known their grievances or of discussing public affairs or of considering or of presenting or preparing any petition memorial complaint remonstrance declaration or other address to His Majesty or to the Governor-General or to both Houses or either House of the Parliament of the Commonwealth.

The Treasury Gardens was a "proclaimed place". Hence, the Court had to address the words immediately following, the charge alleging the woman had, together with others (exceeding the requirement of "twenty") met "on the pretext of making known their grievances ...” Justice Barton, with whom the other judges (Isaacs, Higgins, Gavan Duffy, Powers and Rich JJ) agreed, said the Court had to give regard to the context in which the words appeared. The drafting required that the phrase "for any unlawful purpose or for the purpose

Mary Lamb and Shakespeare's Sister” The Rationalist, Winter Issue, July-August 2011.

${ }^{9}$ [1917] HCA 52, at 2.

${ }^{10}$ [1917] HCA 52, at 2. 
or on the pretext ..." must be considered "in whole". ${ }^{11}$ Was "there ... evidence which should have satisfied the Magistrate, or upon which the Magistrate might properly have been satisfied, that the appellant was one of twenty or more persons who had assembled "on the pretext of making known their grievances". ${ }^{12}$

Barton J said he could "imagine a case where the word 'pretext' would mean the real or ostensible purpose". ${ }^{13}$ In the present case, however, "pretext" was "by the context clearly distinguished from other words in the regulation". First, the words "for any unlawful purpose" appeared, clearly meaning a "real" object, being an unlawful one. Next came the words "or for the purpose", with the word "purpose" being "prima facie ... used in the same sense as before, that is to say, as meaning the real purpose": for example, a real purpose of making known grievances. ${ }^{14}$ Immediately after, came the words (employed in the informations against all three) "or on the pretext".

As to this, Barton J said:

“...as a matter of construction the collocation in which the word 'pretext' is used shows that it is used in contradistinction to the word 'purpose'. In that case the words 'for the purpose or on the pretext' indicate that the persons who have assembled have done so either for the real purpose of making known their grievances or on the pretext, and not really with the purpose, of making known their grievances.”"15

The regulation used "purpose" and "pretext". Therefore, he observed ("or" making them alternatives), it was necessary to find separate meanings for those words. It could not be said, in the context, that "pretext" and "purpose" were identical: "pretext" did not have the meaning of "purpose":

"Being of that opinion, what is the next inference? When persons have assembled on the 'pretext' of making known their grievances, and not for the real purpose of making them known, there is a sham. There is, in such a use of the two terms, a concealment, or a screen, connoted by the word 'pretext' which is not connoted by the direct and frank word 'purpose'. Reading the regulation in that way, as I think we must, the question is what evidence there is here that the purpose for

\footnotetext{
${ }^{11}$ [1917] HCA 52, at 1-2.

12 [1917] HCA 52, at 2.

${ }^{13}$ [1917] HCA 52, at 2.

${ }^{14}$ [1917] HCA 52, at 2.

15 [1917] HCA 52, at 2.
} 
which the persons were assembled was not the true purpose; in other words, that they were assembled on a mere pretext."16

To his own question: "Does that evidence show that the people, however wrong their object, were there holding forth a sham as the reason of their meeting when their real purpose was a different one?” Barton J said:

"I do not think that, whatever may be the fact, the evidence shows that. This Court, it must be remembered, is here not for the purpose of expressing its opinion upon the propriety or impropriety of the conduct of the appellants, but to determine the meaning of the regulation, and whether the Magistrate was justified in finding that the charge with which the appellants have been confronted had been proved. I do not think that anyone hearing the evidence which I have just read would say that there is anything in it upon which the ordinary reasonable mind could conclude that the persons at the meeting were there, not with the object of finding out from the authorities what steps were to be taken to provide cheaper food, but for an ulterior purpose which the cry for cheaper food was merely used to disguise. They are not shown to have been putting forward a sham, and this Court is concerned only with the matter of proof. It seems to me that if we were to hold that the object of these persons was falsely stated, that they had some ulterior object such as to break the law or gain notoriety, we should come to a conclusion unsupported by the evidence. We cannot do that."17

Barton $\mathrm{J}$ then summed up:

- in the regulation "pretext" has a different meaning from "purpose";

- "purpose" refers to the real object;

- "pretext" refers to the professed and not to the genuine object, or to something done under a screen, or a sham. ${ }^{18}$

Therefore, the convictions of Adela Pankhurst, Alice Suter and Jennie Baines, being founded upon charges of breaching the regulation by engaging in a "pretext", should be quashed. Nonetheless, said Barton J, had it been alleged in the information that they "were assembled 'for the purpose' of

${ }^{16}$ [1917] HCA 52, at 1.
${ }^{17}$ [1917] HCA 52, at 2.
${ }^{18}$ [1917] HCA 52, at 2. 
making known their grievances", then on the evidence before the court it was possible that they "might have been properly convicted".

\section{PANKHURST V KIERNAN - JUDICIAL DECISION-MAKING}

On 9 October 1917, a Police Magistrate at Melbourne Petty Sessions sentenced Adela Pankhurst to four months imprisonment with the option of a bond whereby she would undertake not to offend against the Unlawful Associations Act 1916-1917 (Cth) nor attend to speak at any meeting of more than 15 persons without the consent, in advance, of the federal AttorneyGeneral or Solicitor General or a Police Magistrate. Initially, Pankhurst's defence counsel said she would comply with these conditions. Upon her subsequent appearance she opted for prison. ${ }^{19}$

Adela Pankhurst was charged that on 20 September 1917 she had, at Yarraville in the western suburbs of Melbourne, "encouraged the injury of property". The information stated that this was contrary to section 4 of the Unlawful Associations Act:

"Whoever advocates or encourages, or incites or instigates to the taking or endangering of human life, or the destruction or injury of property, shall be guilty of an offence. Penalty: Imprisonment for six months."

Before an audience numbered by police at some 2,000, Pankhurst delivered a speech at a local Yarraville hall, held to assist dependants of men affected by industrial upheaval. Constable McLeod, attending with Constable Kiernan, recorded the speech in shorthand, putting in evidence parts which, he told the Magistrate, constituted "only a small part" of what Adela Pankhurst had said. He added that so far as he knew no one had as a result of the speech destroyed any property. Although shorter and not identical with those of his fellow officer, Constable Kiernan's notes were in evidence too. He said he "missed more" and could write sentences "here and there" only, so had not been able to commit as much to writing as Constable McLeod. This was the prosecution evidence. The defence called no evidence. ${ }^{20}$

As in Pankhurst $v$ Porter, the same six judges sat: Barton, Isaacs, Higgins, Gavan Duffy, Powers and Rich JJ. Two grounds were addressed:

\footnotetext{
${ }^{19}$ Argus, 21 September 1917, p 1.

${ }^{20}$ Pankhurst v Kiernan [1917] HCA 63; (1917) 24 CLR 120 (29 November 1917). (Page citations are from the [1917] HCA 63 online reference.)
} 
- Whether section 4 of the Unlawful Associations Act was valid; ${ }^{21}$ and

- Whether the evidence sustained the proposition that Adela Pankhurst "advocated or encouraged, or incited or instigated ... the destruction or injury of property”.

All judges agreed that on the evidence the last ground could not succeed. As to the first, Higgins $\mathrm{J}$ alone dissented. In a separate judgment, Isaacs $\mathrm{J}$ agreed with the majority, whilst in short concurrences, Powers J stated his agreement with Barton and Isaacs JJ, with Gavan Duffy and Rich JJ each relying upon an earlier case, Farey $v$. Burvett. ${ }^{22}$

As to advocating, encouraging, inciting or instigating destruction or injury of property, the last ground, Barton $\mathrm{J}$ referred to $R v$ Most, ${ }^{23}$ where in the context of criminal libel - seeking to stir others to murder the reigning heads of Europe - Huddleston, B said "encourage" encompassed "to intimate, to incite to anything, to give courage to, to inspirit, to embolden, to realise confidence, to make confident”. Barton $\mathrm{J}$ said these words were not exhaustive, nor in any sense a statutory definition. They might provide assistance in determining what the legislature meant in using the word "encourage” but in any event, he went on, "the word 'encourage' ... is plain enough and needs no definition":

"The applicant's speech cannot be read without perceiving that it was an encouragement, within the meaning of the words quoted, of the injury of property ... The applicant suggested, and tried to induce, the continuance of window-breaking. She showed her approbation of nay, her exultation in - the doing of damage to the value of $£ 5,000$ by the smashing of windows on the previous night. If that was not encouragement, what was it? ... After urging that the makers of excess profits could 'easily stand a strike', and that the Government was careless so far as she and her hearers were concerned, she said these words: - 'We had to adopt other methods; you saw the results of it last night. Panes of glass smashed, - anyway glass windows have got no feeling whatever. Now, friends, if we can hold out we feel we have got the Government in a cleft stick ... The very fact that the people know that they' (the Government) 'are going to get rid of me is stirring them' (the people) 'up to more efforts ... There was $£ 5,000$ worth of damage done, and five persons arrested. One person for

\footnotetext{
${ }^{21}$ A third ground, that the prosecution and conviction breached section 80 of the Constitution - the right to trial by jury, was not pursued by Pankhurst's counsel.

${ }^{22}$ Farey v Burvett [1916] HCA 36; (1916) 21 CLR 433 (8 June 1916). (Page citations are from the [1916] HCA 36 online reference.)

${ }^{23} R v$ Most (1881) 7 QBD 244.
} 
every £1,000 worth of damage. Supposing he’ (Mr Hughes [the Prime Minister]) 'does send some of us to gaol, there will be others to take their places, and it will take a year or two to build gaols to hold us'.,24

Pankhurst had, according to the record, told the crowd that if the military were called out, "the chances were they would shoot the other way, and if $\mathrm{Mr}$ Hughes [the Prime Minister] got some of them to shoot the result would be a failure to obtain recruits”. Then:

"You touch their pockets and you will immediately begin to get something. Therefore, friends, we say to keep on in that way ... The time is coming when the workers are going to say: - We will no longer allow our wealth to be in the hands of a few private individuals. We will no longer allow production to be carried on for profits." ${ }^{25}$

These extracts "speak for themselves", said Barton J. Finding that "encouragement to destroy or injure property" was clear, he concluded:

"I decline to give serious consideration to the view that there was not evidence on which the Police Magistrate could properly find that the utterances of the applicant amounted to the forbidden encouragement within the meaning of the section. They were much more than ample to sustain such a finding.,26

The case then turned on section 4: to sustain the conviction, the law under which Pankhurst was gaoled had to be within the power of the federal Parliament. The Commonwealth relied on section 51 of the Constitution and particularly the defence power:

"The Parliament shall, subject to this Constitution, have power to make laws for the peace, order, and good government of the Commonwealth with respect to:

...(vi) the naval and military defence of the Commonwealth and of the several States, and the control of the forces to execute and maintain the laws of the Commonwealth;

...(xxxix) matters incidental to the execution of any power vested by this Constitution in the Parliament or in either House thereof, or in the 
Government of the Commonwealth, or in the Federal Judicature, or in any department or officer of the Commonwealth.”

In upholding the conviction and thereby finding that the Commonwealth had the power to make the relevant law, Barton J relied upon Farey $v$ Burvett (the Bread Case). ${ }^{27}$

Regulations and an order made under the War Precautions Act 1914-1916 (Cth) fixed the maximum price of bread in proclaimed areas. In Farey $v$ Burvett the High Court, a full bench constituted by the same six judges together with Griffith CJ, said (albeit Higgins J held more narrowly) the order was valid under the defence power. The provision in question was "thought desirable" by the Governor-General in Council "for the more effectual prosecution of the War or more effectual defence of the Commonwealth or of the realm, prescribing and regulating ... (b) the conditions (including times, places, and prices) of the disposal or use of any property, goods, articles or things of any kind; and (c) the requisitioning of any goods, articles, or things of any kind”.

In revisiting Farey $v$ Burvett, Barton $\mathrm{J}$ said that the while an Act or regulation "might not be a measure of defence in time of peace, it might be such a measure in time of war". He referred to the present war, saying that in it "not merely armies but whole nations are engaged in a supreme struggle, which so far as this Empire is concerned is a struggle for the preservation of liberty". He concluded it would be "impossible to say that in such a struggle every part of the Empire was not entitled", and, indeed, even called upon, "to put forth the whole of the resources of its people in men, money, or property, for its self-preservation”. Hence:

"If a measure were capable of contributing to the common defence, it was for the Court to affirm that capability ... [W] [Wether it did so contribute was a question for the ... Legislature. If that body came to such a conclusion by passing an Act, then the function of this Court in deciding whether it was constitutionally valid was to say whether the form of law had been given to something which was capable of assisting in defence .... In the particular case a measure for the conservation of the food supply, or one for the prevention of inordinate profits on its sale, or one for the better provisioning of the people, might or might not be necessary. The Court was to say whether in conceivable circumstances of war it might be so ... there

27 [1916] HCA 36; (1916) 21 CLR 433. In the judgments, Farey $v$ Burvett and the Bread Case are used interchangeably. 
its functions stopped. Whether it was in fact necessary or wise in the particular instance was for the Legislature to determine.”28

This principle was not "confined to questions of food supply" but extended to "all the resources of a people" which may need, in wartime, to "be placed by Parliament at the disposal of the Government for purposes of defence if they are capable of subserving those purposes". The Commonwealth Parliament was, Barton J said, competent to pass "such legislation as may prevent any hampering or dislocation of the work of effectively prosecuting the War, that is, the defence of the country", and it is "not difficult to see that internal disorder may have such results". The destruction of property came within this competency for it "may diminish the resources of the people applicable to their defence", just as may "the wilful taking or endangering of human life", ${ }^{29}$

In Adela Pankhurst's case, however, there was no issue of punishing such "inroads upon life or property". Rather, it was about "the advocacy or encouragement of, and incitements or instigations to, these acts". This, concluded Barton J, is a matter of public disorder and incitement to public disorder:

"The preamble [to the provisions in question] asserts that an association known as the Industrial Workers of the World and members thereof have been concerned in advocating and inciting to the commission of divers crimes and offences, and that it is expedient for the effective prosecution of the present war that laws shall be enacted for the suppression of such practices. It is to continue in force for the duration of the present war and a period of six months thereafter, but no longer ... The Industrial Workers of the World, and also any association which, by its constitution or propaganda, advocates or encourages, or incites or instigates to, the taking or endangering of human life, or the destruction or injury of property, are declared to be unlawful associations ... Other sections deal with ... promotion of actions calculated to interfere with the production, manufacture or transport of troops, munitions of war or foodstuffs; ... the addition of deportation [as a] punishment ...; the printing or publishing of any writing encouraging, \&c., the taking or endangering of human life or the destruction or injury of property; and ... the making of regulations not inconsistent with the Act for giving it better effect." ${ }^{30}$ 
Under the Act, "the associations declared unlawful" and "the things made punishable” were, for Barton $\mathrm{J}$ "... such as may easily tend in greater or less degree to the hampering or dislocation of the proper conduct of the defence of Australia to the extent that such defence is in the hands of Parliament or Government". ${ }^{31}$

In his view, the High Court's responsibility was to say "whether they are capable of so tending". If "yes", then any enquiry by the High Court "into the necessity, or the propriety, or the wisdom of the action" of the law passed "in affirmance of the fact of such tendency or in provision of means for its suppression" would be "trespassing" upon the legislative realm. As the provisions of the Unlawful Associations Act were "calculated to aid, be it much or little, the provisions in the War Precautions Act" and so "to aid the purpose of defence", they were valid. ${ }^{32}$ Hence, for him - and the judges agreeing with him, Pankhurst was rightly convicted and imprisoned.

Yet it is the clash between Isaacs and Higgins JJ which proves the most telling. Albeit it was crucial, Barton J did not asked whether the actual focus of the advocacy - smashing windows - was relevant to the defence power. Isaacs J did. Nevertheless for him, too, there was "not the least doubt" as to the validity of section $4 .{ }^{33}$ Saying the position of Pankhurst's counsel was "hopeless", Isaacs $\mathrm{J}$ too, found both legal and practical support in Farey $v$ Burvett: ${ }^{34}$

- First, in its reliance upon the English Privy Council case The Zamora; $;^{35}$

- Secondly, in its reference to the US Federal Food Control Act which penalised the offence of "knowingly to commit waste, or wilfully to permit preventable deterioration of any necessaries in or in connection with their production, manufacture or distribution”, and "any agreement to exact excessive prices". ${ }^{36}$

The difference between Isaacs and Higgins $\mathrm{JJ}$ centred on the terms of section 4 in its application to Adela Pankhurst's rabble rousing, and the scope

\footnotetext{
31 [1917] HCA 63, at 4.

32 [1917] HCA 63, at 6.

33 [1917] HCA 63, at 5.

${ }^{34}$ Bread Case [1916] HCA 36; 21 CLR 433 (also cited as Farey v Burvett).

${ }^{35}$ In the Matter of Part Cargo ex Steamship Zamora (Appeal No 109 of 1915) $v$ The High Court of Justice Probate, Divorce and Admiralty Divisions (in Prize)(The Zamora) [1916] UKPC 24; [1916] 2 AC 77 (7 April 1916).

${ }^{36}$ [1917] HCA 63, at 5.
} 
of section 51 (vi) and (xxxix) taking into account the division of power between the Commonwealth and the states. Isaacs $\mathrm{J}$ sought to support the provision by reference to "the general intent of the whole instrument, by what precedes and what follows it ..." which, he said, was "quite distinct from the ordinary criminal law of the State". Consistent with Isaac J's view that the section was valid and properly applied against Adela Pankhurst, this distinction was crucial - and Isaacs J could not avoid it, for generally both property and crime are a matter for the states, not for the Commonwealth. Isaacs $\mathrm{J}$ went on, therefore, to observe that the Act was "directed primarily against unlawful associations", but "directed against unlawful associations because of aims and objects inimical to the national capacity for defence":

"That means that what the Act really strikes at as dangerous to the general welfare is the system, or method, or principle, or doctrine, or propaganda, or whatever it may be called, by which human life and property are to be injured or destroyed, not as an isolated instance disconnected with every other criminal act, but as a systematic course of conduct, for the attainment it may be of desired political or economic or social ends. ${ }^{37}$

For Isaacs J, nothing illustrated this better than Pankhurst's own language. He said that the section "no doubt includes incitement to destroy or injure in particular instances”:

"[I]t would reach to an incitement to kill one man or break one window; 73but that would be because the incitement there is part of a general plan or system. It would be as distinct from an ordinary isolated crime dependent on its own origin and confined to its own circumstances, as the instances of German atrocities forming part of their national system of "frightfulness" are distinct from the ordinary local incidents of war. The wholesale smashing of windows was seen by [Pankhurst] to be - and, indeed, it is on the surface - a thing which must surely lead to public insecurity and to the eventual hampering of all transactions in even the necessaries of life, and consequently, if Farey $v$ Burvett is good law, this is a much more obvious case for Federal interference."38

Finally, for Isaacs J, the section showed its "clear design" for "the preservation of Australian life and property generally". These being "obviously essentials for national defence", the contention of invalidity must

37 [1917] HCA 63, at 5-6.

38 [1917] HCA 63, at 6. 
fail. As her language "clearly ... fell within it", therefore, so should the appeal:

"If any question were possible as to any particular suggested property being necessary or not, I think the principles laid down in the Bread Case ..., and still more authoritatively affirmed by Lord Parker for the Privy Council in the case of The Zamora ..., would furnish a complete answer."39

Yet the majority judgment must be looked at against Higgins J's dissent.

Having agreed there was evidence on which the Police Magistrate "could fairly find that [Pankhurst], by her speech, encouraged people to injure property by breaking windows, \&c., in Melbourne”, Higgins J said that for the law's purposes, "it does not matter that [she] hoped to force attention to the needs of the poor". However, there was substance in the ground that section 4 "was ultra vires". The federal Parliament, he observed, has no power to make laws regarding property, or for the protection of property: private property was a matter for state laws. ${ }^{40}$ Nonetheless, it was "urged that the section is valid under the [defence] power, and with respect to 'matters incidental to the execution' of this power". But what connection did smashing windows have with defence of the nation? Higgins J said:

"At first sight, the argument is startling to common sense. How can an Act providing for the protection of private windows from unruly citizens be treated as an Act 'with respect to' the defence of the Commonwealth - defence from the foreign enemy and his adherents? The property in question is not even property of the Defence Department. No doubt every good thing that we get under our internal policy contributes to the strength of the nation against aggression. Civic peace contributes; but so do good sewerage, good education, a good tramway system. But Acts on these subjects are surely not Acts

\footnotetext{
39 [1917] HCA 63, at 6. The Zamora [1916] UKPC 24; [1916] 2 AC 77 involved questions of "prize" in the taking into possession of a neutral ship transporting cargo to Germany (during the first world war), part at least thereof which was munitions or products suitable to the war effort. The Privy Council was concerned with matters of international law and the "Prize Court", its jurisdiction, power and the scope of various regulations and orders. There was no question as to state versus federal laws or matters going to the division of powers in a federal system. The case canvassed the scope of powers in time of war and the nature of defence in the context of international and "prize” law.

40 [1917] HCA 63, at 6-7.
} 
'with respect to ... the naval and military defence of the Commonwealth'. The connection is too indirect and remote."41

Turning to Farey $v$ Burvett, he noted that the finding of validity lay in the War Precautions Act 1914-1916 (Cth) insofar as it provided, by regulation, "limits for the price of bread in certain populous localities". This turned on the nature of war:

"Defence is a matter of force - force to be used against the enemy; and if that force is likely to be diminished by scarcity of bread, by excessive prices of bread, or dissipated in the riots which so commonly accompany the want of bread, it may well be a defence measure to keep the price of bread low. As in the case of a besieged city it may well be necessary or expedient, for the purposes of defence, to provide for sufficient food for all the inhabitants, and at fixed prices. Moreover, the very sub-section of the War Precautions Act which gave the power to make regulations fixing prices ... specified 'the more effectual defence of the Commonwealth' as an object to be aimed at by the regulations. In short, Parliament treated the fixing of prices as conducing to the defence of the Commonwealth; and, in my opinion, we are bound to accept the statement of Parliament that it does so conduce unless we can see that the statement is obviously untrue or absurd." 42

That the federal Parliament in the Bread Case legislated expressly "with respect to" defence was compelling. Explicit reference to "defence" eliminated any enquiry by the High Court as to "whether the measure is effectual or futile, wise or unwise". That was for the Parliament. Neither, he said, was it for the High Court "to listen to evidence as to the necessity of the measure under the circumstances". ${ }^{43}$

This did not mean that the absence of such "defence" reference was fatal. Still, the ordinary rules of interpretation required that it be "clear on the face of the instruments" that the Parliament intended:

- that the price of bread should be fixed for the purposes of defence; and

- that the donee meant to use the power conferred by section 51(vi).

\footnotetext{
41 [1917] HCA 63, at 6-7.

42 [1917] HCA 63, at 7.

43 [1917] HCA 63, at 7.
} 
When, "under ordinary circumstances" a law is within the competence of state Parliaments alone, said Higgins J, yet the federal Parliament passes legislation entering the state's sphere, "clarity on the law's face" is "all the more vital”. ${ }^{44}$

In the present case, he pointed out, state legislation already existed. Under the federal Act, the penalty was six months' imprisonment. Under the Crimes Act 1915 (Victoria), as an "abettor or counsellor of a misdemeanour", Pankhurst could have suffered two years' imprisonment. So "not only could the states make laws with respect to protection of properties within their state boundaries"; they had done so. This contrasted with the position vis-à-vis bread: the states could not systematically regulate bread prices throughout Australia. To control them across the country, bread prices would have to be framed on "some uniform, general scheme" - which the federal Parliament alone could do. ${ }^{45}$

Distinguishing bread prices from property protection, Higgins $\mathrm{J}$ reemphasised the need for a link between the defence power and the provisions:

"The connection between the power to defend Australia and maintaining the fighting force of Australia in full strength by regulations as to bread is direct and obvious; the connection between the power to defend Australia and the protection of property in the several States from injury is indirect and remote." ${ }^{46}$

Saying he did not now decide one way or the other, Higgins $\mathrm{J}$ observed that if the federal Parliament had replicated the War Precautions Act wording - expressly stating that the provision in question was for the "defence" of Australia, then it may be that the High Court could be bound to accept it. But Parliament had not. Turning to what the Act did say, Higgins J noted that the reference to the Industrial Workers of the World (IWW) had no application to Adela Pankhurst, for she was not a member of the IWW and it was not suggested she was:

"But the point is that Parliament has not purported to legislate under the defence power ... It purports, indeed, to make the law "for the effective prosecution of the present war"; but that is not necessarily the same thing. For instance, one can conceive of a position in which all danger to Australia has vanished, and yet the War - the same war is still being prosecuted for the purpose of obtaining Constantinople for the Greeks or the Russians, or Jerusalem for the Jews, or Dalmatia

\footnotetext{
44 [1917] HCA 63, at 7.

45 [1917] HCA 63, at 7.

46 [1917] HCA 63, at 8.
} 
for Italy. For aught that appears, the draughtsman may have thought that the constitutional limitations were suspended during the War, and that any Act aimed at the effective prosecution of the War would, under all circumstances and for all purposes, be treated as valid. But the constitutional limitations are not suspended; we have to decide in accordance with the Constitution ...,47

As to the majority's reliance on Farey $v$ Burvett, Higgins $\mathrm{J}$ pointed out that in deciding that case, and still, for him "the greatest care is needed in watching the attempts to extend the limits" of the defence power. There was "no reason whatever" to doubt the "propriety" of the decision, but the case did not lay down "the doctrine that any law ... the Federal Parliament may make on any subject in time of war is valid":

"The Federal Parliament is not empowered by the Constitution to make any law that it likes for 'the peace, order, and good government of Australia'; but it is empowered to make any law for the peace, order, and good government of Australia 'with respect to ... the naval and military defence of the Commonwealth'., 48

In Farey $v$ Burvett he had "applied his mind" to the three steps there under consideration, namely, Act, regulation and order:

"The net result was that the price of bread was fixed, and under the authority of Parliament legislating with respect to defence. Power was conferred on the Governor-General to make regulations 'for the more effectual prosecution of the War, or 'the more effectual defence of the Commonwealth' as to (inter alia) 'the conditions (including times, places and prices) of the disposal or use of any property goods articles or things of any kind'.,"49

If the federal Parliament sought to pass a "private property protection" law, it must "at the very least", show by "express words or necessary intendment" that it "regards the law as necessary or expedient for the distinctive object of the defence of Australia"; namely, that "it is applying its mind to the defence of Australia". A war for the defence of Australia could take place outside the country and "in distant part", or in defence of "the Empire and of the world", so that a law could in such circumstances be legitimate under the defence power. However, such a law might be exercised

${ }^{47}$ [1917] HCA 63, at 8.
${ }^{48}$ [1917] HCA 63, at 9.
${ }^{49}$ [1917] HCA 63, at 9. 
lawfully or unlawfully. If exercised unlawfully, then the execution of such law would be invalid. This is what made the distinction between the present case and the Bread Case:

"In the latter, the question was one of an executory power, 'perhaps too wide in its tenor' but which was exercised lawfully (so far as it appeared on the record) by the donee of the power, namely the Governor-General. In the former (the present case), the High Court was 'dealing with a power executed - executed by Parliament, for a purpose which is not, taken by itself, sufficient in law under all circumstances - 'the effective prosecution of the War'., 50

Therefore, said Higgins J, the conviction must be quashed.

With Higgins $\mathrm{J}$ in the minority, the appeal was dismissed. Adela Pankhurst - who had been released on bail pending appeal - was returned to prison, serving until January 1918 despite a petition carrying thousands of signatures. ${ }^{51}$

That this was the outcome is not, however, an end to the matter. The conflation, on the part of the majority, of advocacy for smashing windows with selling bread at an inflated price, or a challenge to exporting wheat when the domestic price of bread lifts it out of workers' grasp or severely reduces their ability to buy it, is questionable. This highlights the impact political considerations have upon judicial decision-making, particularly the impact of wartime on what is determined to be lawful and unlawful activity according to interpretation of law at the highest levels of the judiciary.

\section{COMMERCIAL CONDUCT VERSUS POLITICAL ACTION}

Even the most cursory look at Farey $v$ Burvett confirms it as a very different case from that of Adela Pankhurst and her advocacy for breaking glass. Farey $v$ Burvett was decided at the height of the war; the decision in Pankhurst $v$ Kiernan came down a full year before the Armistice was declared ending fighting on the Western Front. Farey $v$ Burvett involved trading in the commercial arena for the making of profits in defiance of regulated prices; Pankhurst $v$ Kiernan involved one woman's defiance in the public streets.

\footnotetext{
50 [1917] HCA 63, at 9.

51 Renowned feminist and peace activist Vida Goldstein spearheded the petition's formulation and garnering of signatures. See Coleman (Adela Pankhurst) Above $n 7$ pp 83-84.
} 
Does the difference mean Higgins J's dissent should have prevailed: that no justification lies in the defence power for federal legislation making unlawful the conduct for which Pankhurst was prosecuted, convicted and gaoled? Or was the majority view to be preferred: that "defence" supports a law sufficiently wide to penalise speech calling for the breaking of shop windows?

Farey $v$ Burvett's popular shorthand title "the Bread Case" - used interchangeably by the High Court in Pankhurst $v$ Kiernan - is not insignificant in assessing the strength of the arguments on both sides. Farey was fined for breaching a regulation prescribing the price for selling bread in Melbourne and its suburbs during wartime.

Bread prices were regulated by the War Precautions Act 1914-1916 (Cth), authorising the Governor General to make regulations and orders he thought "desirable for the more effectual prosecution of the War, or the more effectual defence of the Commonwealth or of the realm". Such regulations and orders were restricted to "prescribing and regulating" amongst other matters "the conditions (including times, places, and prices) of the disposal or use of any property goods articles or things of any kind”. On 24 March 1916, by regulation "proclaimed areas" were declared for the principal populated parts of Australia, measured by a 10 mile radius from Sydney and Melbourne General Post Offices (GPOs), and within lesser miles radius of the other capital cities and certain other districts. The Governor General was empowered to fix maximum prices for sale of bread and flour in the proclaimed areas. Farey's conviction resulted from his selling bread in a proclaimed area at a price higher than that set by the Governor General. In other words, he was engaged in profiteering.

In the words of Griffith CJ, did the defence power (s. 51(vi)) warrant "all this legislative action" and, hence, the conviction? The defence power provided no scope for the federal Parliament to regulate food prices during peacetime. This lay with the states. ${ }^{52}$ The contention for Farey was that the defence power allowed regulation of food prices or "necessaries of life" during war only insofar as relating directly to the armed forces or military operations, not to the needs of the civilian population or, as Isaacs J put it:

"The contention, and the only contention, on behalf of the appellant, is that even in time of war, whatever be the national exigency, it is wholly incompetent to the Commonwealth Parliament to make any provision with respect to the sale of the necessaries of life, except so far as relates directly to the armed forces or some actual military operation. The needs of the civil population, it is said, are altogether

52 See also T R Bevin and H V Evatt "Price-Fixing in Australia during the War", (1921) 3 Journal of Comparative Legislation and International Law 202-12. 
outside the limits of Commonwealth protection, because within the meaning of the Australian Constitution no scheme of national defence can possibly comprehend them. Monopoly, according to the argument gravely presented, may lay the community under private contribution, may sap their energies or unconscionably reduce their means of living, with the most direct consequences of impeding the nation in its struggle for existence, and yet the national Government, charged by the Constitution with the duty of universal defence, is by the same instrument forbidden to remove the impediment. The remedy suggested for such an evil is in the State powers." 53

However, state powers rather than federal intervention was, for the High Court as a whole, no answer. For Isaac J:

“...though the States may, in directions not contravening express prohibitions, most advantageously act by means of their own constitutional powers in aid of the common object, yet this possibility does not ensure a remedy at all, and certainly does not ensure a remedy on broad national lines, with unity of purpose and action, even if the requisite knowledge were always possessed by the State authorities to enable them to appreciate the necessities of the entire situation." 54

In accordance with the principle established by the US Supreme Court in M'Culloch v. Maryland, ${ }^{55}$ as adopted in Jumbunna Coal Mine, No Liability v. Victorian Coal Miners Association, ${ }^{56}$ the federal Parliament must have a discretion to make laws in "the manner most beneficial to the people" so long as, within the context of the particular power, the end is legitimate and all means employed to the end are not prohibited, are appropriate, and are consistent with the letter and spirit of the Constitution. In affirming this, Griffith CJ, said that measures for defence "includes preparation for war in time of peace and any such action in time of war as may conduce to the successful prosecution of the war and defeat of the enemy". It was "obvious" that the question "whether a particular legislative act is within [the defence power] may fall to be determined upon very different considerations in time of war and time of peace". However ".. any measure which may have the effect of tending to secure an adequate food supply to Great Britain during the

\footnotetext{
53 Farey v Burvett [1916] HCA 36, at 9.

${ }^{54}$ [1916] HCA 36, at 9.

${ }^{55}$ McCulloch v Maryland 17 US 316; 4 Wheat. 316; 4 L. Ed 579 (1819).

56 Jumbunna Coal Mine v Victorian Coal Miners' Association (No 2) [1908] HCA 95; (1908) 6 CLR 309 (6 October 1908).
} 
War, and so increasing, or preventing the diminution of, the resources of that part of the Empire would be a measure tending also to the more efficient defence of the Commonwealth as a part of it". ${ }^{57}$ This followed because Australia's defence and security in time of war was dependent upon that of Great Britain.

Further, said Griffith CJ, the power to legislate on defence extended “... to any law which may tend to the conservation or development of the resources of the Commonwealth so far as they can be directed to success in war, or may tend to distress the enemy or diminish his resources, as, for instance, by the prohibition of trading with him or with persons associated with him". ${ }^{58}$ The power to make laws with respect to defence being a paramount power, if coming into conflict with state powers - that is, powers not granted to the federal Parliament through the Constitution, then the latter must give way.

Crucially, however, in Farey $v$ Burvett the entire tenor of the judgments of each of the seven High Court justices - identical with the bench in the Adela Pankhurst cases, apart from the presence of the Chief Justice - was as to the centrality of resources and their significance in terms of the war effort, for the "control of finance or trade may be the most potent weapon of all":

"History as well as common sense tells us how infinitely various the means may be of securing efficiency in war. Sumptuary laws have always been common war measures. No one would dispute that the regulation of the supply and price of food in a beleaguered city would be a proper, and might be a necessary, war measure. The legislative act now in question is in substance a sumptuary law."59

Emphasised time and again, particularly by Griffith CJ, it was, however, essential to apply a principal test:

"Can the measure in question conduce to the efficiency of the forces of the Empire, or is the connection of cause and effect between the measure and the desired efficiency so remote that the one cannot reasonably be regarded as affecting the other?"60

This was the test at the forefront for Higgins $\mathrm{J}$ in Pankhurst $v$ Kiernan, in his observation that Farey was convicted in the Bread Case under legislation coming before Parliament after Melbourne wharf labourers had refused to

${ }^{57}$ Citing Barton J Farey v Burvett [1916] HCA 36, at 2.

58 [1916] HCA 36, at 3.

59 [1916] HCA 36, at 3.

60 [1916] HCA 36, at 3. 
load flour onto ships sailing to Great Britain and allied countries until the price of bread in Australia was reduced:

"[Melbourne wharf labourers] were persuaded to abandon this attitude and to trust to Parliament; and Parliament may well have considered that in providing for the fixing of prices they were providing for 'the more effectual defence of the Commonwealth' [as the section expressly averred] by 'securing cheap bread and the supply of food for Great Britain and her Allies and the allied armies' ..."61

Patently, this was not so with the law said to support the Pankhurst conviction. For Higgins $\mathrm{J}$ the heart of the matter lay in whether or not there was a link between smashing windows - or, more specifically, advocating their destruction, and the pursuit of the war effort or sustaining Australia's defence. There was, for him, no such link nor the shadow of one.

Then to Barton and Isaacs JJ's proposition that the position in the United States sustained and supported the notion that destruction of shop windows was a matter of "defence". It was here that Isaacs $\mathrm{J}$ found support in the Federal Food Control Act, observing that states' rights in the US are "even more extensive than in Australia" and that albeit "necessaries" was defined in the US Act, "being a matter of legislative discretion", its scope could have been extended. ${ }^{62}$

Higgins $\mathrm{J}$ joined issue, explicitly challenging reliance upon the United States' position. Albeit the Civil War of 1861-1865 led to a "severe strain" on the limits of the Presidential and Congressional powers of the United States, with a "host of crimes ... not previously punishable by law" being created, he said, there was "no trace of any Statute making it illegal to injure or to encourage injury of private property". So far as he could discern, there was "no precedent in any defence legislation of Congress for any such legislation as we have here to consider". In the present war, Congress had legislated for sale of wheat, flour, meal, beans and potatoes by the President "at reasonable prices", together with "fixing the prices of coal and coke". Furthermore (as with Farey $v$ Burvett) the US legislation conferring this power "expressly recited" the measure as being "essential to the national security and defence". ${ }^{63}$

However, for Isaacs J, section 4 was "if possible, more clearly than Farey's Case within the ambit of [federal] power, because the destruction of or injury to property - including bread - involves its utter waste to the community, and consequently is much more serious than a rise in price, which

\footnotetext{
${ }^{61}$ Pankhurst $v$ Kiernan [1917] HCA 63, at 7.

62 [1917] HCA 63, at 5.

63 [1917] HCA 63, at 7.
} 
still assumes the possibility of obtaining and using the commodity". ${ }^{64}$ Yet it is ironic that "including bread" should have been noted by Isaacs $\mathrm{J}$ at this point, and it shows the slippage involved in the endeavour to bring Adela Pankhurst's case within the scope of the earlier decision: for bread was not in issue here; shop windows were.

None of the other judges in Pankhurst $v$ Kiernan confronted the nub of the problem. Even though Isaacs J sought to do so, notably he - as with the other four - avoided addressing the very substance of the difference between the legislation in question in Farey $v$ Burvett and its application to the offence there in question, and the legislation said to apply to Adela Pankhurst - and the conduct asserted to bring her within the scope of the defence power. He did endeavour to countermand the notion that section 4 was "too wide" in its reference to "property". Hence, on the contention that because "some property might be unsuitable for war purposes, yet such property is covered by the section”, he constructed a twofold answer:

"First, no one can ever say that anything is useless for war purposes, even in the narrowest sense; but next, and chiefly, all property in Australia is part of our national resources, or, in the language of [The Zamora's] Lord Stowell, part of the 'common stock' to which the Australian people - one people in war, and for that purpose knowing no State divisions - have a right to regard collectively as its means of support in every way for the purposes of this war, both in the lines and behind them."

Yet for Higgins $\mathrm{J}$ this was no answer.

Nor can it go unremarked that Farey $v$ Burvett lacked any reference or even allusion to circumstances within the defence power having any parallel with the scope contested for by the majority in Pankhurst $v$ Kiernan, Griffith CJ cited two examples: ${ }^{66}$

- ... a Commonwealth law enacting that any person plying for hire with a boat or launch in any harbour or river in the Commonwealth shall obtain a licence from a Commonwealth officer. Such a law, if passed in time of profound peace, could not possibly be regarded as a law substantially dealing with defence. An identical law passed in time of

\footnotetext{
64 [1917] HCA 63, at 5.

65 [1917] HCA 63, at 5.

${ }^{66}$ Farey $v$ Burvett [1916] HCA 36, at 4.
} 
war, and limited in its operation to the duration of the war, might obviously be a necessary war precaution.

- ... a law passed by the Commonwealth Parliament in time of profound peace prohibiting the accumulating of food stuffs ("forestalling" or, today, "hoarding") could not be regarded as substantially an exercise of the defence power. In time of war the same act might well be made a capital offence.

Transport and food are easily assessed as crucial to defence and with a connection to it - troop and cargo (equipment) movements, maintenance and upkeep of defence forces, control of waterways and traffic on waterways, ensuring a proper supply of foodstuffs - all directly relevant to the prosecution of war or "defence of the realm", all with an identifiable link.

The principle that a law relating to defence would need to be seen as being capable of "conducing to the more effectual prosecution of the War" was crucial for Griffith CJ. The Court could, he said, take judicial notice of the fact that the past season's harvest "was most abundant", with "vast quantities of wheat, far exceeding the possible consumption of the Commonwealth", awaiting export, whilst wartime meant "the supply of freight is deficient". Therefore, for economical and "other reasons" exporting surplus to the United Kingdom or the allied nations "may be highly desirable for the more efficient prosecution of the War". It seemed to follow, he concluded, that any law "which may tend, with or without the aid of other measures, to encourage such export may be conducive to the more efficient conduct of the War". ${ }^{67}$

\section{WARTIME EXIGENCY VERSUS FREE SPEECH}

Where do Pankhurst $v$ Porter and Pankhurst $v$ Kiernan stand in the potential for politics to play a role in decision-making of police, prosecution and courts during wartime? To those who see the law and particularly judicial decision-making as above socio-political sensibilities, it may be unsettling to focus upon why Adela Pankhurst and, in Pankhurst $v$ Porter, her companions, might be seen as subject to such a contingency.

Yet the prosecution in Pankhurst $v$ Porter signified a watershed. Prior to this, wartime demonstrators, including Pankhurst, were prosecuted under state or "civilian" laws. ${ }^{68}$ The new approach confirmed a decision that it was time

\footnotetext{
${ }^{67}$ [1916] HCA 36, at 4.
}

68 News coverage following the progress of demonstrations and arrests confirms that initially state ("civilian”) laws were employed against Adela Pankhurst. When she persisted in her right to demonstrate, federal laws and regulations under the defence power were ultimately used. See "Street Disturbances. Adela Pankhurst Again 
to make an example of these agitators through condemnation under defence laws. Then, in arresting and prosecuting the women under Regulation 27, police and prosecution decided the women engaged in "pretext". Had the women's calls for action been accepted as embodying a genuine concern about prices taking food out of the "ordinary" labourer and housewife's reach, the trio would have been prosecuted for engaging in just that purpose. "Pretext" - or as the High court put it, "sham" - would not have been in issue.

By "pretext", the prosecution asserted the three pretended concern about prices, poverty and food for the poor, using their platform to agitate, stir up trouble, court publicity. Barton J himself cast doubt upon the women's bona fides: "I do not think that, whatever may be the fact, the evidence shows that ['pretext' exists here]". ${ }^{69}$ He alluded to the "gaining of notoriety" as a possible basis for a prosecution under "pretext".

This embodies stereotypes of women in the public and political arena, and general stereotypes of women qua women. Historically, women have been expected to be and remain silent, to defer to fathers and husbands, not take up causes. ${ }^{70}$ As for "women as women", embedded in the law is the notion that women are not to be trusted, mendacity being seen as an inherently female trait. ${ }^{71}$ Such stereotypes held sway in 1917. In dismissing the appeal in the lower courts Judge Johnston said that in a conflict of testimony the Magistrate had to determine which evidence he would accept and "felt no doubt that he should accept that of the police as against that of a number of highly strung women ..."72

In Pankhurst $v$ Porter, the prosecution misfired. This meant that in Pankhurst $v$ Kiernan, Adela Pankhurst was faced with a Court which had been obliged, upon the evidence, to exculpate her once. Could the Court countenance exculpation for a second time, particularly as this time, she stood without fellow miscreants?

Arrested. Charge of Encouraging Damage” The Argus, 24 September 1917, p 6; "Miss Adela Pankhurst Goes to Gaol" The Advertiser 5 September 1917, p 7; also J Smart "Feminists, Food and the Fair Price: The Cost of Living Demonstrations in Melbourne August-September 1917” Labour HistoryNo 50 (May 1986) pp 113-131.

${ }^{69}$ Pankhurst $v$ Kiernan [1917] HCA 63, at 3.

${ }^{70}$ On traditional notions of women's place, see C Smith-Rosenberg Disorderly Conduct - Visions of Gender in Victorian America (Oxford: Oxford University Press, United Kingdom, 1986); J Damousi "Socialist Women and Gendered Space: The Anti-Conscription and Anti-War Campaigns of 1914-1918” Labour History, No 60 (May 1991), pp 1-15, http://www.jstor.org/stable/27509044 (accessed 30 January 2011).

${ }^{71}$ See for example H Kennedy Eve Was Framed - Women and British Justice, (London: Chatto \& Windus, UK, 1992), updated edn Vintage, London, 2005.

72 “Adela Pankhurst. Conviction Upheld. Stay of Proceedings Allowed” Argus, 13 September 1917, p 6. 
Adela Pankhurst was vulnerable in coming alone before the High Court in circumstances where only days before she, along with Suter and Baines, had won an acquittal. Her continuing defiance of the war whatever the cost and refusal to obey measures said to be in support of war, particularly in ignoring or even promoting hunger and poverty amongst the civilian population, was a clear affront to those in power. The authorities' desire for an example to be made was a matter of notoriety. That Pankhurst was both a leader and a charismatic character was on record Australia-wide and throughout the Empire. Her exploits were reported at home and abroad. Her mother's view of her conduct was sought, with predictable maternal condemnation. ${ }^{73}$ The Prime Minister, Billy Hughes, publicly and privately spoke of deporting her. ${ }^{74}$

That judges are distanced from the social and political realities, from assumptions, stereotypical perspectives, their own socialisation, and pressures of the times in which they sit is not infrequently contradicted by judicial pronouncements from the bench. Judgments relating to cases involving women, whether sexual offences or marital killings, ${ }^{75}$ or social security and welfare fraud ${ }^{76}$ are cited in this regard. More generally, so too are cases with political implications - the trials and appeals of alleged IRA bombers, for example. ${ }^{77}$

${ }^{73}$ Adela Pankhurst was sent out to Australia by her mother, who paid her fare, concerned that Adela was taking attention away from Christabel, Mrs Pankhurst's favoured daughter. See "Mrs Pankhurst. Ashamed of Adela and Repudiates Her" The Advertiser, 9 March 1917, p 6. See also Fran Abrams, Freedoms Cause - The Lives of the Suffragettes, (London: Profile Books, UK, 2003); "Adela Pankhurst: Biography”, Spartacus Educational, http://www.spartacus.schoolnet.co.uk/WpankhurstA.htm (accessed 29 January 2011). 74 “Miss Adela Pankhurst. Suggested Deportation” Mercury, 22 September 1917, p 8; see also WM Hughes to K Murdoch, 3 September 1917, quoted in L F Fitzhardinge, William Morris Hughes - A Political Biography, Vol 2 ("The Little Digger"), Angus \& Robertson, Sydney, Australia, p 277; S Hogan "Pankhurst, Adela Constantia Mary (1885-1961", Australian Dictionary of Biography, http://adbonline.anu.edu.au/biogs/A120729b.htm (accessed 29 January 2011); S Hogan, "Pankhurst, Adela Constantia Mary (1885 - 1961)" Australian Dictionary of Biography, Vol 12 (Melbourne: Melbourne University Press, Australia, 1990) pp 372374.

${ }^{75}$ See for example Kennedy Eve Was Framed, (1992, 2005); S M Edwards Sex and Gender in the Legal Process, (London: Blackstone, UK, 1996).

${ }^{76}$ See for example T Nyman, "Opinion: Jail for Social Security Fraud Except in Exceptional Circumstances”, Law Society Journal Vol 35 (1997), pp 7-21; Edwards, Sex and Gender, 1996.

${ }^{77}$ For example the "Birmingham Six"; the "Guildford Four", the "Maguire Seven". Also see $R v$ Richardson, Conlon, Armstrong and Hill EWCA Crim. (20 October 1989); $R v$ Ward (1993) 96 Cr App R 1; $R v$ McIlkenny \& Ors (1991) 93 Cr App R 
Pankhurst $v$ Kiernan involved a defiant woman with an overtly political cause. It is impossible not to be struck by the failure of the majority judgments to address adequately or at all the question of a link between smashing windows and defence. The judges engage in complete omission or, as with Isaac J, elision or sleight of hand. Higgins $\mathrm{J}$ alone turned his mind to the matter explicitly in issue. For him, it was clear. As Barton $\mathrm{J}$ said in Pankhurst $v$ Kiernan the function of the High Court in deciding whether a law purporting to be made under section 51(vi) of the Constitution was indeed valid, was "to say whether the form of law had been given to something which was capable of assisting defence". ${ }^{78}$ Neither he, nor four of his brother judges, followed this path.

Yet if Adela Pankhurst had advocated the smashing of windows, intentionally and without compunction for the damage it would cause should her listeners bow to her advocacy - as all six judges had agreed, the prosecutorial decision was clear. State laws for the protection of property were the answer. State, civilian law was the non-political pathway to prosecution.

Higgins J's dissent took the politics out of judicial decision-making. That his brethren followed a path of upholding the conviction, despite the lack of connection between the defence power and what Adela Pankhurst was found to have said and done, confirms that political considerations are not remote from judicial decisions made during times of war and dissent.

287; Maguire Seven (1992) 94 Cr App R 133; E Guittet "Judicial Abuses in the Fight against Terrorism: The Guildford Four (1974), the Maher Arar Case (2002), and the Constitutional Bana of Batusuna (2003)", Paper presented at the annual meeting of The Law and Society Association, Montréal, Canada, 27 May 2008, http://www.allacademic.com/meta/p237314_index.html (accessed 3 February 2011); C Mullins Error of Judgment: The truth about the Birmingham bombings (Dublin: Poolbeg Press, Ireland, 1987); B Hilliard 'Soldiers of Nothing', New Law Journal, Vol 140, No 6442, pp 163-65; B Schurr 'Expert Witnesses and the Duties of Disclosure and Impartiality: The lessons of the IRA cases in England', NSW Legal Aid Commission, Sydney, Australia, http://www.aic.gov.au/events/aic\%20upcoming\%20events/1993/ /media/conferences/ medicine/schurr.ashx (accessed 3 February 2011).

${ }^{78}$ [1917] HCA 63, at 3. 